\title{
Tales of Ordinary Leadership. A Feminist Approach to Experiential Learning
}

\author{
Silvia Gherardi \\ Barbara Poggio ${ }^{1}$ \\ Università di Trento. Dipartimento de Sociologia. \\ Research Unit on Comunication, \\ Organizational Learning and Aesthetics \\ silvia.gherardi@soc.unitn.it \\ bpoggio@soc.unitn.it
}

Received: 12-09-2007

Accepted: 28-02-2008

\begin{abstract}
Feminist practice and theory have always conferred value on narrative knowledge produced through storytelling, mainly because of its ability to stimulate reflexive thought. In our contribution we intend to present and discuss a training methodology founded on memory work and designed to stimulate an individual and group reworking of the leadership dimension, and of the gender and leadership relationship. We will describe a narrative workshop conducted with groups of women working in managerial positions and based on the perspective of workplace learning through experiential reflexivity. The narrative methodology proved to be a particularly effective tool: it gave the participants a chance to conduct retrospective analysis of their past work experiences (individual and organizational), and it generated - due to the interaction with other stories (those furnished in the training activity and those provided by other trainees) — different interpretative perspectives and new meaning configurations in order to face working life and organizational dynamics.
\end{abstract}

Key words: narrative knowledge, gender, memory work, storytelling.

Resumen. Cuentos de liderazgo ordinario. Un enfoque feminista del aprendizaje experiencial.

La práctica y la teoría feminista han conferido siempre valor al conocimiento producido a través de las narraciones, principalmente por su capacidad de estimular el pensamiento reflexivo. En nuestra contribución nos proponemos presentar y discutir una metodología de formación basada en el trabajo sobre la memoria, a fin de estimular un replanteamiento individual y de grupo sobre la dimensión del liderazgo y su relación con el género. En particular, haremos referencia a un taller narrativo realizado con grupos de mujeres que trabajan en posiciones directivas, en la perspectiva del aprendizaje en los lugares de trabajo a través de la refexividad experiencial. La metodología narrativa ha demostrado ser un ins-

1. This article is the result of an entirely collaborative effort by the three authors. If, however, for academic reasons individual responsibility must be assigned, Silvia Gherardi wrote the introduction, the first section, and the conclusion; Barbara Poggio wrote sections 2, 3, and 4. 
trumento particularmente eficaz: ha ofrecido a las participantes la oportunidad de analizar retrospectivamente una esperiencia de trabajo pasada (individual y organizativa), generando, gracias a la interacción con otras narraciones (las proporcionadas por la actividad de formación y por las participantes en la misma), distintas perspectivas interpretativas y nuevas configuraciones de significado a fin de enfrentarse a las dinámicas organizativas y de la vida laboral.

Palabras clave: conocimiento narrativo, género, trabajo sobre la memoria, narración de historias.

\section{Summary}

Introduction

1. Reflection, reflexivity and narrative in feminist methodology

2. Leadership as a situated and gendered practice
4. The use of narrative methodology: an example Concluding remarks

References

3. A reflexive workshop on leadership

\section{Introduction}

Feminist practice and theory have always conferred value on narrative knowledge produced through storytelling, mainly because of its ability to stimulate reflexive thought. In our contribution we intend to present and discuss a training methodology founded on memory work and designed to stimulate an individual and group reworking of the leadership dimension, and of the gender and leadership relationship.

We will describe a narrative workshop conducted with groups of women working in managerial positions and based on the perspective of workplace learning through experiential reflexivity. The training objective was to address the issue of leadership as situated practice. To this end, narrative stimuli were given to the participants in order to prompt more general reflection about male and female modes of power management (and about the connected practices of domination/exclusion). The purpose was to highlight the social and cultural factors that influence these differences, and to offer perspectives alternative to dominant patterns.

The narrative methodology proved to be a particularly effective tool: it gave the participants a chance to conduct retrospective analysis of their past work experiences (individual and organizational), and it generated — due to the interaction with other stories (those furnished in the training activity and those provided by other trainees) - different interpretative perspectives and new meaning configurations in order to face working life and organizational dynamics. 


\section{Reflection, reflexivity and narrative in feminist methodology}

The concepts of reflection and reflexivity have assumed great importance in the contemporary sociological literature, and especially in studies on workplace learning (Gherardi and Poggio, 2006).

Reflection concerns the rendering of personal experience amenable to awareness and analysis. It entails the actor's ability to engage in a process of introspection and to impose some sort of self-control on his/her intellectual operations. Its principal purpose is to conduct retrospection appraisal of individual action in order to improve future practice (Schön, 1983, 1987). Despite the diversity of the literature on reflection and learning at work, reflective practice is conceived as a means of examining and re-examining experience. The focus on re-examining experience is to notice tensions and contradictions in order not to take experience for granted. Uncertainties, discrepancies and dissatisfactions are said to precipitate reflection and are central to any notion of reflection (Boud and Walker, 1998; Boud, Cressey and Docherty, 2006). This conception leads to the development of a model for learning from experience that focuses on how reflection might be facilitated as a key element of learning.

Reflexivity, especially in the ethnomethodological meaning of the term (Garfinkel, 1967), instead consists in the practices of accountability, observability and referability of social action. It concerns the close interweaving among symbols, languages and actions, and their connections with the context. It is the outcome of the separation or breakdown between subject and object and the need for «accountability» - by which is meant making the world comprehensible to oneself and to the other members of a collectivity. To account for an event or an experience implies language use, narrative practices, storytelling. It is a relational practice, taking place in an interactional context, and it is mainly social and not simply cognitive and emotional.

Reflexivity is therefore a characteristic of all order-producing social activities. Moreover, "the essential reflexivity of accounts» (Garfinkel, 1967: 67) is used to create a sense of orderliness for action but reflexively creates that selfsame context.

While reflection looks back at the past in order understand and to alter the future, reflexivity is anchored in present practice, in identification of the assumptions and priorities that shape our interpersonal relations. Introspection is not undertaken with a view to action, but is instead an integral part of it and is embedded in every interaction. Indeed, Rothman (1997) defines the reflexive process as «interactive introspection». When we refer to "reflexive leadership» we wish to point that the process of narrating leadership creates the context for experiencing leadership and reflecting on its practices.

Reflection and reflexivity perform a central role in the feminist debate, particularly with regard to so-called «feminist methodology» (Bowles and Duelli Klein, 1983; Harding, 1987). Various writers have emphasised the need for reflexive approaches which enable individuals, and women in particular, to 
start from personal experience (Roberts, 1981, Stanley and Wise, 1983) and from self-awareness (Reinharz, 1983; Held, 1993) to question the traditional paradigms of «objectivity» and "detachment» that have supported the hegemony of maleness in the dominant models of science. The main means to foster reflexive thought is indubitably narrative, owing to its ability to enhance retrospective glance and memory work. What is meant by retrospective thought can be illustrated by referring to the story of the stork told by Karen Blixen in Out of Africa (1938).

The story runs as follows. A man lived in a small house near a pond. One night he was woken up by a loud noise. He ran out of his house and in the darkness headed towards the pond, repeatedly tripping, falling and getting up again. Following the noise he found a leak in the pond wall, which he repaired and then went back to bed. When he looked out of the window the next morning, he saw that his footsteps had traced the outline of a stork on the ground. In this short story, retrospective glance is metaphorically represented by the man looking out of the window. His work of the night is finished, and it is only a posteriori, in the marks left on the ground, that he gives meaning to his movements, sees a pattern, shapes his experience.

It is through recounting that the signs and traces of experience are pieced together and acquire complete meaning. The pattern of a life or an event emerges retrospectively when thought becomes reflexive, when it turns onto itself to compose a narrative, to give shape to what was indistinct.

Besides the backward introspection that induces reflexive thought to appropriate or re-appropriate personal history, also of especial importance in feminist methodology is «memory work». In the 1980s a group of German women in Hamburg published a collected volume which reconstructed, on the basis of individual experiences, the social processes that construct female sexuality (Haug et al., 1987). The methodology of memory work was then transferred to other contexts, for instance the socialization of women to academic work, or the therapeutic treatment of women victims of abuse. Put briefly, the expression «memory work» refers to the process by which the historical-cultural self is interwoven with practical/social relations. It looks at the self as a historical product, as an on-going trajectory, as a cultural product (form of the discourse), and as a relational practice. It is based on the assumption that some change in the present can only be brought about if that past is subjected to «dispassionate» analysis.

Narrating is a way to re-appropriate experience, to «re-member» in the sense of reconstructing a «dismembered» body (Brady, 1990), and to gain new awareness. Narrating makes it possible to construct a memory and to retrieve something that would otherwise be lost (Cavarero, 1997). It is an opportunity for individuals to acquire renewed projectuality and a more sophisticated ability to interpret and make sense of the events that they encounter (Poggio, 2004). In short, it is «a practice of transformation, reflection, reconstruction, re-cognition and re-structuration of the self» (Gamelli, 1995: 116). 


\section{Leadership as a situated and gendered practice}

Leadership has long been a topic of central concern for organizational studies. However, with the course of time attention has shifted from the role and function of the leader to the practice of leadership, from a personalized and functionalist view to one that emphasises the relational and constructive dimension of leadership action and the process of the collective creation of meaning and consensus (Alvesson, 1992; Piccardo, 1998). Among the emergent features of this new view of leadership there are some that we believe to be particular significant.

The first is the growing awareness that leadership is not so much a personality trait or a natural gift as a relational practice, something that «one does» by relating to others (Manz and Sims, 1991). Thus, a prescriptive approach intended principally to identify categories and models (the charismatic leader, the participative leader, the transactional leader, and so on) is replaced by an experiential one in which the focus is on experiences of leadership, the relational dynamics involved in leadership, its motivational and emotional features, and especially its relationship with power. The interweaving between leadership and power has been stressed by several authors (Kets de Vries, 1993; Sievers, 1996), but in this case the object of analysis is the subjective relationship with power and its implications for interpersonal relations.

The second emergent feature is connected to the «situatedness» of leadership (Bruni, Gherardi and Poggio, 2005). Like every practice also leadership has a situated nature, in the sense that it cannot be conceived in absolute and general terms but must be contextualized in specific relational situations and systems. Situated leadership means that it is situated in a physical context, in the dynamics of interactions, in the language and in the body.

Therefore, leadership is also gendered. It has been historically constructed as a male sub-text by producing images of leadership which are difficult to relate to femaleness (Alvesson and Billing, 1997) or by describing styles and models of female leadership which stand as alternatives to traditional leadership (Hegelsen, 1990; Loden, 1985). A frequent finding of these studies is that, whereas men are mainly characterized by a "transactional» style of leadership (involving the exchange of results for rewards and command through control), women display distinct abilities in «transformational» leadership: a management style which emphasizes relationality and seeks to foster positive interactions and trust relations with/among subordinates, to share power and information and to encourage employees to subordinate their personal aims and interests to collective ends.

In short, these studies relate female leadership styles to a specific (natural or socialized) orientation of women towards communication, cooperation, affiliation and attachment, and to a conception of power as control not over the group but by the group. Some authors explain this distinctive style of female leadership as resulting from the influence of primary socialization (Chodorow, 1978), which develops women's affective and relational resources and a propensity to communicate with others, to listen to them, and to concern themselves 
with their needs. Accordingly, the argument runs, the activities that society have traditionally assigned to women (child-raising, care for the physical and psychological well-being of family members, the settlement of conflicts) have developed a culture of responsibility and an ethic of care whereby women constantly endeavour to satisfy the needs of everyone.

A more critical interpretation (Kanter, 1977; Beccalli, 1991; David and Vicarelli, 1994) suggests that, because women have not usually been able to wield formal authority in the organizations for which they work, they have been forced to develop other strategies to that end, most notably an ability (typical of those in positions of inferiority) to "feel» and anticipate the reactions of others.

Moreover, analysis of the organizational literature on leadership shows that it is constructed to maintain and reinforce hegemonic masculinity. Images of male sexual functions and of patriarchal paternalism appear to be rooted in the way that the leader's action is described. One observes a seductive game, modulated in the masculine, which seduces those who identify with the stereotypes of maleness and virility (Calás and Smircich, 1991).

\section{A reflexive workshop on leadership}

In recent years feminist critiques within organization studies (Gherardi, 2003) have led to a redefinition of the concept of leadership and a redefinition of training practices. Approaches more oriented to relationality, empowerment and reflexivity have appeared and therefore courses and methods designed to re-elaborate personal and professional experience, to create sense and consensus collectively, to develop creativity, and to foster autonomy and self-awareness. The aim is no longer to teach efficacious leadership styles or models, nor to define skills to be developed; rather, it is to stimulate individual and collection reflection, for example, through the sharing of leadership stories recounted by the trainees. A reflexive approach to leadership enables individuals, and women in particular, to start from personal experience and from self-awareness to question the traditional paradigms of «objectivity» and "detachment» that support the dominant models of knowing in organizations and producing knowledge on organizations.

Reflection and individual or group analysis of situations in which the participants have wielded authority in organizations furnish occasions for self-knowledge or even its redesign which involve not only the cognitive, cultural and affective dimensions of the individuals concerned but also the strategic and structural ones of the organization. The assumption is that the group is a crucial learning resource because it enables different experiences to be shared and compared.

The importance of leadership learning workshops has been emphasised also outside the feminist approach by various authors, among them Senge (1991), and recent years have seen the growth of a large body of literature on the use of self case studies and narratives in learning workshops (Casula, 2003; Griffith, 1999; Piccardo, 1998). During these workshops, accounts of work experiences 
written by the participants are discussed and analysed, and usually rewritten (Piccardo, 1998). Or accounts are exchanged by the participants so as to foster a "dialogic conversation» which generates multiple points of view, stimulates analysis and deconstruction of the assumptions of canonical stories, and encourages the creation of alternative plots, thereby fostering a learning process which is at once dialogic, divergent, emergent and collaborative (Abma, 2003).

We now describe a specific instance of a narrative workshop based on some of the assumptions just outlined, and the focus of which was the relationship between leadership and gender. Four editions of the workshop were organized, each of them attended by twelve women with managerial positions in the local administration of a North Italian town.

The course was designed around a number of themes representing the core of leadership in traditional textbooks: rationality, control, decision making, strategic thinking. Each of them was framed in relations to its opposite (the suppressed term). On this basis, the workshop was divided into five day-long sessions intitled:

The retrospective gaze, in which the temporal dimension in organizational life and in the individual working career seen as planning and anticipation was explored by contrasting it with the idea of looking backward and retrospective sense-making. This session started with Karen Blixen's story of the stork.

Leadership in the feminine? The interrogative form was proposed in order to explore the mainstream conception of leadership in contrast with its hypothetical translation «in the feminine». This session relied on a story by Italo Calvino.

Rationality and emotionality. The two concepts were played one against the other starting with an excerpt from Daniel Pennac.

The myth of control. Control and being in control is the founding myth of organization studies and it was contrasted with the image of flow and being in the flow of time and things. The image was based on a passage from Michel Tournier's Friday or the Pacific Limbo which describes the change of relationship between Robinson Crusoe and Friday after the explosion on the island and the end of its rational order.

Designing the future. Strategy and decision-making as anticipation of the future action was contrasted with a relational and contextual view of time, power and future scenarios. The impetus was provided by Tolstoj's description of the decision process of General Kutuzof about the Russian Army's retreat.

Each session required the participants to read and to write stories, according to the following schema:

- The facilitator read aloud «the story of the day», a literary passage intended to introduce the proposed theme in a imaginative way and in the context of mundane life. 
- Following the narrative stimulus, each participant was invited to write a short story relating to her professional experience in the organization and which centred on the topic of the day.

- The stories were told, exchanged and analysed in smaller groups. The group as a whole worked together in order to bring out shared and divergent views on the experience narrated, the plots used, the processes by which meaning had been reconstructed and attributed, and the underlying cultural models.

- Cutting across the various themes addressed provided the stimulus to reflect on a number of issues intrinsic to the topic of leadership: its relationship with power, recognition of its conflictual dimensions, and the importance of learning to recognize and understand the emotions connected with the exercise of authority in the participants' organizational contexts.

The key component of the workshop was reflexive learning, defined as «a process which involves dialogue with others for improvement or transformation whilst recognizing the emotional, social and political context of the learner» (Brockbank, McGill and Beech, 2002: 75). Narrating leadership and analysing it collectively and in relation to organizational change is a way of constructing a more or less shared understanding of what leadership is and how it may be "done» in a shared workplace. Storytelling provides not only the opportunity to discuss «things that happened or could happen», but also the opportunity of performing one's identity as power holding in situated circumstances.

\section{The use of narrative methodology: an example}

This section presents one day, and one theme, in our narrative workshop, in order to illustrate the process and reflect on managerial education. The subject of the day (the second in the course) was the relationship between gender and leadership.

The stimulus for reflection, narrative writing and storytelling in groups was a story entitled «Fanta-Ghiro» taken from Italo Calvino's Italian Folktales, of which a summary follows.

A king had three daughters but no sons. The king was of a sickly disposition. One day a Turkish king declared war against his land, but the king was too ill to take command of his army. So his three daughters offered to take his place. The father at first refused, because commanding an army was not women's work. But then, given the seriousness of the situation, he agreed to send his eldest daughter, but on the condition that she dressed and behaved like a man. He warned her that if she started talking about women's things, his trusted squire would bring her straight home. The daughter left for the war, but during the sea voyage she saw a gaily coloured fish and remarked that she wanted a ball gown in the same colours. So the squire took her straight back home. The same thing happened to the second daughter. During the voyage, when 
she saw the colourful sails of the fishing boats, she began talking about the fabrics she wanted to decorate her bed chamber. So the third daughter, FantaGhiro, then set off to fight the war, even though she was still so small that her armour had to be padded before she could put it on. The sea voyage passed without incident, and the young princess went to parlay with the enemy king. The king was intrigued by the «iron general» and set traps to see whether he was not really a woman. He took Fanta-Ghiro into the armoury and then into the garden, asking question to catch her out. Fanta-Ghiro passed all the tests until the king invited her to go for a swim. This forced her to find an immediate excuse to return home But she left behind a letter explaining who she really was. The king, by now in love, followed Fanta-Ghiro and asked her to marry him. Peace was made, of course, and when Fanta-Ghiro's father died he left his kingdom to his son-in-law.

This story was particular stimulating for the participants, owing to various features which emerged very clearly from both the narratives produced during the workshop and the group and plenary discussions. The first of these features concerned the symbolic order of gender apparent in the story, which the participants recognized as an organizational archetype (gender segregation) and a dilemma (adopt male or female behaviour?) that all of them had encountered to some extent in their professional lives.

Added to this was the fact that the plot of the story was substantially ambivalent. On the one hand, an unconventional figure of a woman was presented and valorised; but on the other, the end of the story depicted an absolutely canonical scenario in which the conventional order was restored through matrimony and inheritance by the male offspring, thereby complying with one of the essential principles of narrative: the restoration of the violated order (Bruner, 1990).

The co-presence of these features was highly stimulating to the workshop participants. It elicited reactions ranging from admiration, through identification and frustration, to anger, and it generated numerous stories which developed aspects and nuances of the relationship between gender and leadership as experienced by the women. They recounted experiences of discrimination, episodes of revenge and affirmation, introspective analyses of their relationships with leadership and power, anecdotes about when they had to disguise themselves as men, or when they refused to do so.

There follows an example of one of the stories produced.

That morning Allegra climbed the stairs to her office thinking that yet another of those day was about to begin.

Another one of those difficult days in which tiredness due to work (positive) would be accompanied by the subtler, more insidious weariness (negative) that comes from fighting a losing battle.

Once again it was going to be the same old struggle, the one that since her promotion to a position of responsibility she had been fighting in a public organization still trapped in a formal, individualistic and - why notmale mentality. Absorbed in her thoughts, as Allegra turned the corner she ran into Dr. Nero, her boss, who had always resented her promotion. 
She tried to slip past him [...] too late! «Allegra, good morning! I hope that today we can finally get that matter sorted out [...]».

"Right, that matter [...] for God's sake», thought Allegra.

The «matter» concerned lessons on theory of organizations and old-style leadership which Nero based on his twenty-year experience of leadership declined in the masculine.

As if leadership can be taught! And then, what leadership? As if there's a universal model of it!

«Remember that personnel management requires an iron fist [...]!». Dr. Nero's voice boomed in the background as Allegra remembered the altercation between them the previous day: «You give too much importance to others, to personal aspects. You want to understand everything and everyone [...] Set value on differences! What rubbish. And then let me say, all that baloney that you think is so important $[\ldots]$ creating a climate, building a team [...] it's nothing but a waste of time, it's just women's stuff [...]».

The ringing of her mobile phone saved Allegra from her memories and from Dr. Nero. She rushed into her office slamming the door behind her.

For a moment she teetered towards the idea that Dr. Nero might be right, that there was no place for the emotions in work, no place for caring about others, for valuing differences [...] But then she shook her head, whispering «But what sort of world would that be?» as she settled into her chair. «No, I'm not the leader that Nero wants me to be, but what do I care? And then an iron fist would clash with my name!», she said to herself as she smiled and switched on her computer.

The story of Allegra is a mixture of invention and reality. However, when set within the training context and shared with the group, it immediately assumed a situated character and an explicit organizational significance, eliciting shared reflection on individual experiences of leadership and on the leadership models of the organizations to which the participants belonged. The story discloses a rejection of the symbolic order of gender dominant in the woman's organization and awareness that the female is constructed in organizations as the "other» with respect to a maleness still hegemonic in concrete and discursive practices.

The emphasis on the diversity of leadership styles between men and women, and the reference to valuing differences, prompted the group to discuss the ambivalence inherent in its participants' organizational cultures. The discussion brought out a double-bind situation in which women filling leadership roles are required to behave like men but without abandoning their femaleness.

Finally the group's discussion of the story highlighted that leadership is tied to a person's relationship with power. This relationship is strongly gendered for social-cultural reasons: on the one hand there is the male view of power as power over others; on the other there is the female version of power as power for others, with the dichotomy being resolved by a view of power as with others, in a domain of relation, exchange, cooperation and responsibility where gender has citizenship (Parker Follet, 1924; Clegg, 1989). 


\section{Concluding remarks}

In this paper we have sought to demonstrate the importance of a narrative methodology in generating reflection and reflexivity with respect to working and organizational experience, and to leadership processes in particular. Our treatment has been based on feminist practice and theory, and the emphasis that these have placed on the centrality of reflexive thought and memory, as well as on the need to redefine the mainstream models of leadership aimed at maintaining and reinforcing hegemonic masculinity.

From this perspective, experiential learning is based on the interaction between two processes distinctive of narrative workshops: narrating and listening. It is, in fact, above all in this interaction that individual indentities, as relational and performative processes, are produced and negotiated and that the meaning of experience is constructed. The collective processing of common experiences elicited in the workshops through the reciprocity of narrating and listening, stimulates the participants to reconsider their positioning in individual, professional and organizational relations and to redefine the meaning of their experiences, generating transformative practices and processes.

By describing our reflexive workshops on leadership, therefore, we have sought to show how storytelling stimulates reflection and reflexivity, or retrospection and reflective learning from experience on the one hand, and storytelling as a means to reflect on current practices and to create further contexts on the other.

This comes about in particular when the stimuli used consist of polysemic stories; that is, ones which stimulate different valid interpretations (Boje, 1995) or which touch the deepest-lying emotions (Gabriel, 2000), as in the case of the story of Fanta-Ghirò. The tale produced by Allegra in response to this stimulus, and its subsequent discussion by the group, furnishes a clear example of experiential learning where listening and storytelling interweave to produce occasions for reflecting upon and transforming leadership practices and power relations, not just at the individual level but within a process of sharing and exchanging.

\section{References}

ABMA, Tineke A. (2003). «Learning by telling. Storytelling workshop as an organizational learning intervention». Management Learning, 34, 2, p. 221-240.

ALVESSON, Mats (1992). "Leadership as social integrative action: A study of a computer consultancy company». Organization Studies, 13, 2, p. 185-209.

ALVESSON, Mats and BILLING, Yvonne (1997). Understanding gender and organizations. London: Sage.

BECCALLI, Bianca (1991). «Per una analisi di genere nella sociologia economica». In: Donne e uomini nella divisione del lavoro. Ed. G. Bonazzi, C. Saraceno, B. Beccalli. Milano: Angeli.

BuIXen, Karen (1937). Den afrikanske Farm. Copenhagen: Gyldendal. Engl. transl.: Out of Africa. London: Putnam, 1938. 
BOJE, David (1995). «Stories of storytelling organization: A postmodern analysis of Disney as "Tamara-Land"». Academy of Management Review, 38(4), p. 997-1035. Boud, David; Cressey, Peter and DocherTy, Peter (eds.) (2006). Productive reflection and learning at work. London: Routledge.

BOUD, D. and WALKER, D. (1998). «Promoting reflection in professional courses: the challenge of context». Studies in Higher Education, 23, 2, p. 191-206.

Bowles, G. and Duelli Klein, R. (eds.) (1983). Theories of women's studies. London: Routledge \& Kegan Paul.

BRADY, E. M. (1990). «Redeemed from time: Learning thorugh autobiography». In: Adult Education Quarterly, 41, 1, p. 43-52.

BROCKBANK, Anne; MCGILl, Ian and BEECH, Nic (2002). Reflective learning in practice. Aldershot: Gower.

Bruner, Jerome (1990). Acts of Meaning. Cambridge, Massachusetts: Harvard University Press.

Bruni, Attila; Gherardi, Silvia and Poggio, Barbara (2005). Gender and Entrepreneurship: an Ethnographical Approach. London: Routledge.

Calás, Marta B. and Smircich, Linda (1991). "Voicing Seduction to Silence Leadership». Organization Studies, 12, 24, p. 567-602.

CASUlA, Consuelo (2003). Giardinieri, principesse, porcospini: Metafore per levoluzione personale e professionale. Milano: Franco Angeli.

CAVARERO, Adriana (1997). Tu che mi guardi, tu che mi racconti. Milano: Feltrinelli. CHODOROw, Nancy (1978). The reproduction of Mothering. Berkeley: University of California Press.

ClEGG, Stewart (1989). Frameworks of power. London: Sage.

DaVID, P. and Vicarelli, G. (eds.) (1994). Donne nelle professioni degli uomini. Milano: Angeli.

FuYNN, P. (1991). The ethnomethodological movement: Sociosemiotic interpretation. New York: Mouton de Gruyter.

GABRIEL, Yiannis (2000). Storytelling in organizations: Facts, fictions, fantasies. Oxford: Oxford University Press.

GAMELLI, Ivano (1995). «La conoscenza di sé e il pensiero introspettivo: la meditazione». In: DemeTrio, D. (ed.). Per una didattica dell'intelligenza. Il metodo autobiografico nello sviluppo cognitivo. Milano: Franco Angeli, p. 113-123.

GARFINKEL, Harold (1967). Studies in ethnomethodology. Englewood Cliffs, N.J.: Prentice-Hall.

GHERARDI, Silvia (2003). «Feminist Theory and Organizational Theory: a Dialogue on New Bases». In: KnUdSEN, H. and Tsoukas, H. (eds.). The Oxford Handbook of Organizational Theory: meta-theoretical perspectives. New York: Oxford University Press.

GHERARDi, Silvia and Poggio, Barbara (2006). «Feminist challenges to mainstream leadership trough collective reflection and narrative». In: BOUD, D.; CRESSEY, P. and DOCHERTY, P. (eds.). Productive reflection and learning at work. London: Routledge, p. 181-192.

GRIFFITH, William (1999). «The reflecting team as an alternate case teaching model. A narrative, conversational approach». Management Learning, 30, 3, p. 343-361. HaRding, Sandra (1987). «Is There a Feminist Method?», in HARDING, Sandra (ed.). Feminism and methodology. Bloomington: Indiana UP, p. 1-15.

HAUG, Frigga et al. (1987). Female sexualization: A collective work of memory. London: Verso. 
Hegelsen, Susan (1990). The female advantage. New York: Currency Doubleday. HeLD, Virginia (1993). Feminist morality: Transforming culture, society and politics. Chicago: The University of Chicago Press.

KANTER, Rosabeth Moss (1977). Men and women of the corporation. New York: Basic Books.

KeTS De VRIES, Manfred F. R. (1993). Leaders, fools and imposters. San Francisco: Jossey-Bass.

LODEN, Marilyn (1985). Feminine leadership or how to succeed in business without being one of the boys. New York: Times Books.

MANZ, Charles C. and SimS, Henry P. Jr. (1991). «Superleadership: Beyond the myth of heroic leadership». Organizational Dynamics, 19, p. 18-35.

Parker Follett, M. (1924). Creative experience. New York: Peter Smith.

PICCARDO, Claudia (1998). Insegnare e apprendere la leadership. Milano: Guerini.

PogGIO, Barbara (2004). Mi racconti una storia? Il metodo narrativo nelle scienze sociali. Roma: Carocci.

REINHARZ, Shulamit (1983). «Experiental analysis: a contribution to family research». In: Bowles, G. and Duelli Klein, R. (a cura di). Theories of women's studies. London: Routledge \& Kegan Paul.

RoberTs, Helen (1981) (ed.). Doing feminist research. London: Routledge \& Kegan Paul.

ROTHMAN, Jay (1997). Resolving identity-based conflict: in nations, organizations and communities. San Francisco: Jossey-Bass.

Senge, Peter M. (1991). «The leader New Work. Building learning organizations». Sloan Management Review, 3, 1, p. 7-23.

SCHÖN, Donald A. (1983). The reflective practitioner: How professionals think in action. New York: Basic Books.

SIEVERS, Burkard (1996). "Greek Mythology as a Means of Organizational Analysis. The Battle at Larkfield». Leadership and Organizational Development Journal, 17 (6): 32-40.

SCHÖN, Donald A. (1987). Educating the reflective practitioner. San Francisco: JosseyBass.

STANLEY, Liz and WiSE, Sue (1983). «Back into personal» or: our attempt to construct feminist research». In: BOWLES, G. and DuELLI, R. (a cura di). Theories of women's studies. London: Routledge \& Kegan Paul.

TOURNIER, Michel (1967). Vendredi ou limbes du Pacifique. Paris: Gallimard. Engl. transl.: Friday or the Other Island. London: Collins, 1969. 